\title{
Lucrative Circus in the Desert: Economics of Burning Man
}

\author{
Wadim Strielkowski \\ Department of Agricultural and Resource Economics, University of California, Berkeley, Giannini \\ Hall, CA 94720, Berkeley, United States; strielkowski@berkeley.edu
}

\begin{abstract}
Burning Man is probably the most famous art festival in the world. What started as a bonfire ritual for a small group of friends held on San Francisco beach in 1986, has evolved into an iconic event. Held annually for one week before the Labor Day weekend, the festival attracts over 60,000 participants each year and yields over $\$ 8$ million in tickets and contributions.

This preprint reveals some preliminary results from the economic analysis of Burning Man that is based on the unique data from over 500 surveys collected during several Burning Man events between 2012 and 2018.

The paper's main findings demonstrate that Burning Man is not some hippie get-together with lots of booze and drugs. Instead, it is a lucrative and exclusive event that is attended by bright, wealthy and well-educated people, both from the United States and abroad. A typical Burner is a 32-old childless male with a college degree and an average annual income above $\$ 100,000$ who attended Burning Man at least two times before and who spends between $\$ 5,000$ and $\$ 6,000$ on tickets, fares, gear, and supplies.
\end{abstract}

Keywords: Burning Man, festivals, art, public events, self-reliance, radical expression

\section{Introduction}

Burning Man is perhaps the most intriguing and world-famous art and performance festival that takes place annually around Labor Day and lasts for one week in Nevada's Black Rock Desert in the United States with seemingly no structure and order. A bonfire ritual for a small group of friends has evolved into one of the most popular art festivals in the world (Brill, 2018). Since the festival moved to the Nevada desert in 1996, thousands of people come with cars, camper vans, buses to build the Black Rock city, a town that appears as an official settlement on the Nevada state records and officially exists for about 10 days each year. Some people passionately and lovingly call it "magic circus in the desert" for its remarkable spirit and atmosphere.

Burning Man exhibits various forms of art, including the gigantic wooden statue of "The Man" (a magical symbol and a mascot of the festival), together with sculptures, art installations, interactive forms of art, dozens of art cars, temporary exhibitions, concert shows, bars, cafes, restaurants, discotheques, as well as the largest wooden structure in the world (called "The Temple"). The majority of art installations presented at Burning Man take months to construct in the desert by the teams of volunteers prior to the event and are burnt or destroyed at the end of the festival. Nowadays, the Burning Man festival attracts over 60,000 people (the number has grown from 50,000 in 2011 to 65,000 in 2014) each year and annually yields over $\$ 8$ million in tickets and contributions.

Burning Man event can be described as a social experiment that takes place annually in a temporary community. The Burning Man culture is inspired by the perceived need for a change from the norm that is upheld in the outside world where people are used to living in a world that is shaped by institutions, service workers, and commercial transactions. In the Burning Man festival however, these things all take a back seat as people from all walks of life are given a leeway to fully express themselves as they like. 
The community at the Burning Man festival is usually engaged in the exploration of a variety of self-expressions of an artistic nature which are formed with an aim to create a celebratory atmosphere for the pleasure of the participants in the festival. To achieve the main goal of the festival which is to create an environment whereby all the participants make the most of their time at the Burning Man, participants, who are referred to as "Burners", are all encouraged to participate actively in the numerous events held at the festival.

The Burning Man does not normally focus on a single topic and each year the new theme is selected. This can be attributed to the various goals fostered by attendees participating in the festival who are also known as Burners. The participants in this event are usually guided by ten principles whose main purpose is to evoke the cultural ethos drawn from the event (Karlin, 2016). These principles were written by Burning Man co-founder and "spiritual father" Larry Harvey (who passed away in April this year) serve as the universal criteria for the general culture of the movement and include: 1) radical inclusion, 2) gifting, 3) de-commodification, 4) radical self-reliance, 5) radical selfexpression, 6) communal effort, 7) civic responsibility, 8) leaving no trace, 9) participation, and 10) immediacy (Burning Man Organization, 2018).

This preprint aims at presenting the Burning Man event in the new light as a luxurious and expensive festival that is mainly targeted at the upper social strata of the society. The research us based on the on the unique data from over 500 surveys collected during several Burning Man events between 2012 and 2018 using random, semi-random, and snowball sampling. Contrary to the public opinion and numerous clichés, Burning Man festival is no longer a badly-organized event but rather a place for the representative of the modern elites meet and entertain each other.

\section{Academic studies of Burning Man}

Since the inception of the Burning Man event, numerous scholars from a wide variety of disciplines have been involved in a discussion of the social, cultural, as well as business and management implications of the festival (Kozinets, 2002; Gilmore and Van Proyen, 2005; Sherry and Kozinets, 2007; Chen, 2009a; Turner, 2009; White, 2013; Craig, 2013; or Radziwill and Benton, 2013). There is even an academic guide embedding various formats of publications created by the academic community of Burning Man or by the Burning Man Organization available at the Florida International University library platform (FIU, 2018).

Figure 1 shows the word art shape created in Wordle based on the question in our questionnaire: "If you were to describe Burning Man to a stranger unfamiliar with the event, which words would you choose?". One can see a plethora of concepts and ideas associated with the event.

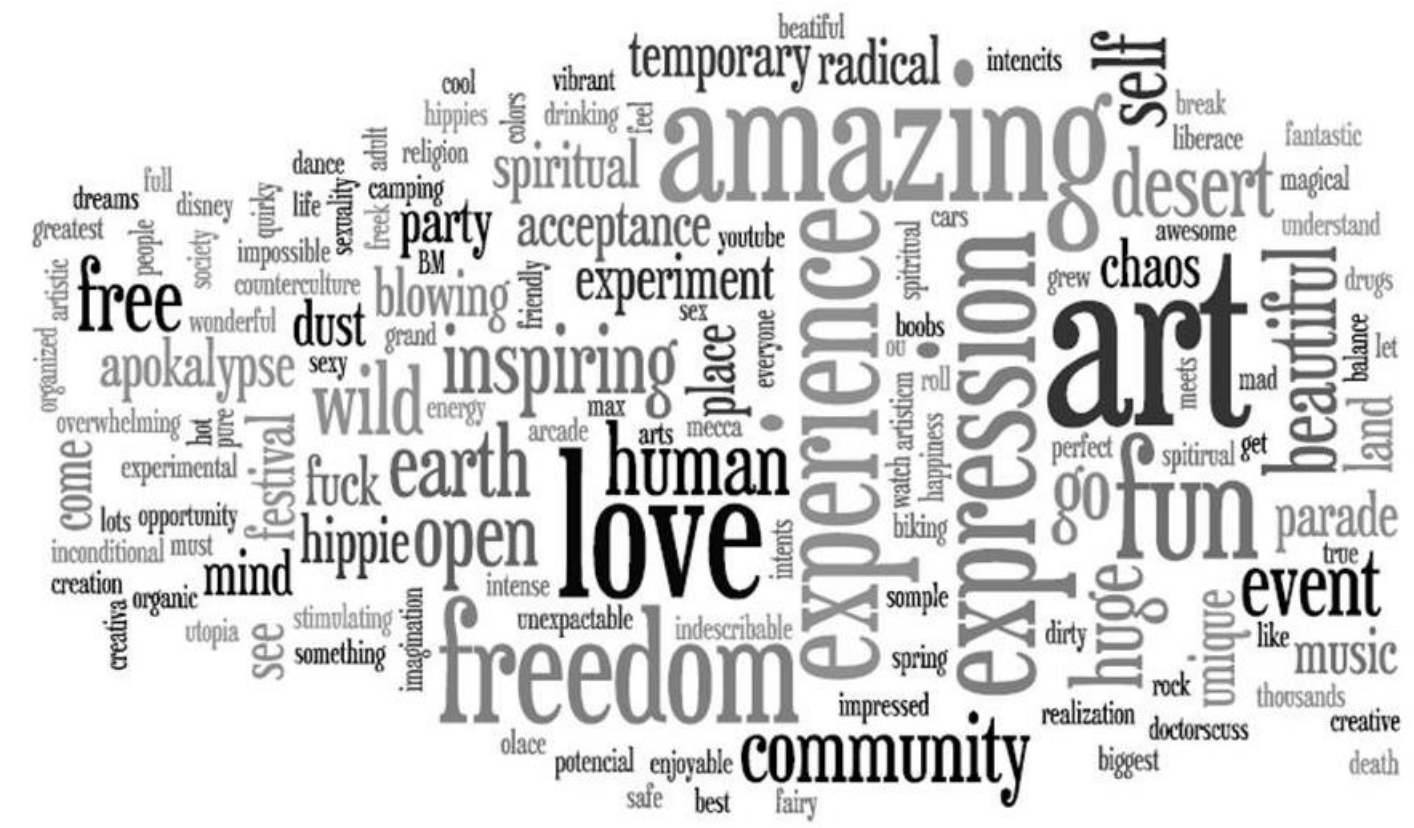

Figure 1. Burning Man Wordle-based cloud word shape. Source: Own results 
The activities that people engage in during their time at the festival has been a topic of discussion in which scholars and critics alike have disagreed on in more than one occasion (Kozinets and Sherry, 2004; Doherty, 2006; Chen, 2009b). The bone of contention in this matter is the 'immorality' aspect of the festival. Rules and regulations of a conventional nature are minimal and continued to evolve as the size of the gathering grew. The annual festival has a reputation for nudity, sex and debauchery mostly because of the fact that nudity is allowed (in keeping with the Burning Man principle of radical expression, nudity is also considered to be a costume).

\section{How much does it cost to go to Burning Man?}

The biggest puzzle of Burning Man is to find a ticket that allows one to enter Black Rock City. Over the years, the price of the Burning Man tickets has been changing. In the first years of its existence, the admission to the event was free, however starting from 1991, the regular ticket price started to be charged. The ticket prices quickly mounted from $\$ 15$ in 1999 to $\$ 505$ in 2017 (including a $\$ 80$ vehicle pass).

At first, the tickets were sold at the gate, however, starting from 2008 the tickets started to be sold over the Internet. However, due to the growing popularity of the event and the skyrocketing number of visitors, limitations had to be introduced due to the regulations of the State of Nevada and environmental protection regulations. In 2012, the Burning Man Project (a non-profit organization that stands behind the event) made an unpopular decision to introduce the ticket lottery system and in 2014 the vehicle pass was introduced (Figure 2).

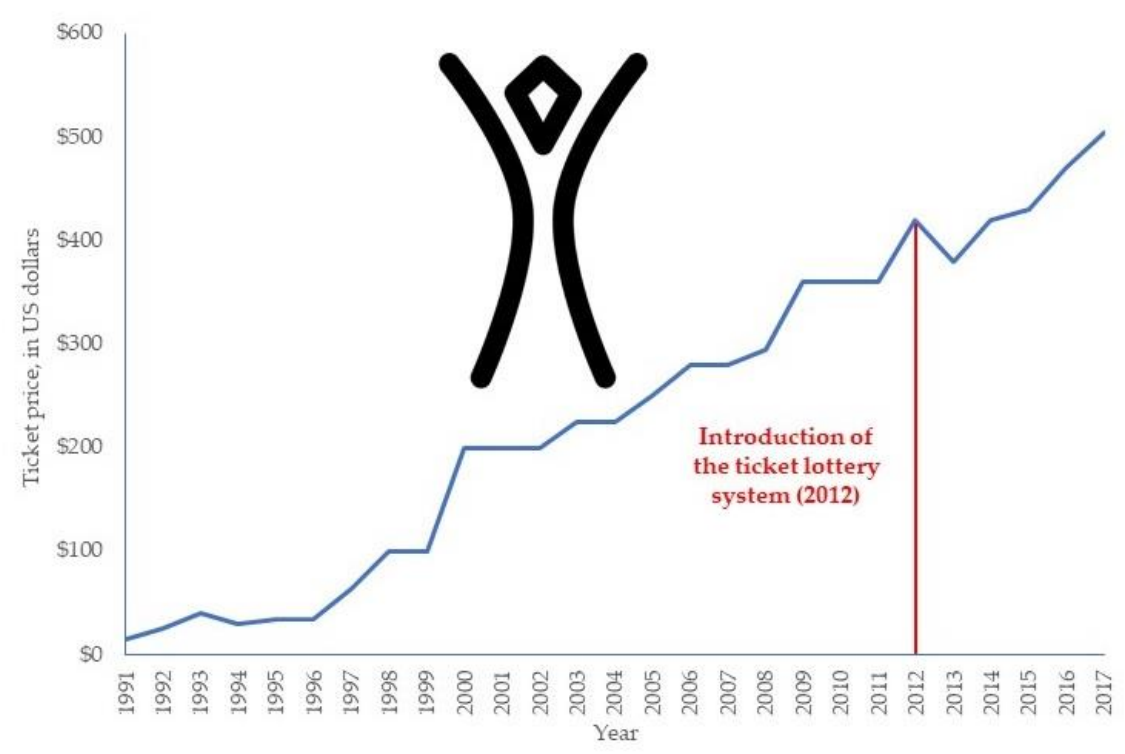

Figure 2. Burning Man ticket price. Source: tickets.burningman.org (2018)

However, our findings suggest that once a Burner, you will always find a ticket to attend the event. More than half of our respondents obtain their tickets through friends or via other sources. This tendency increases with the years of experience at Burning Man. All respondents who paid \$110 or more for their first ticket attended Burning Man at least 3 times. Respondents who paid \$370-380 for their first ticket attended Burning Man 7 times or more. Contrary to our expectations, most of the respondents who paid at least $\$ 390$ dollars for their ticket, attended Burning Man only once. This suggests that some wealthy people who paid a large amount of money for the first ticket did not come again. A possible explanation would be that festival's opportunities are not justified by the large amount of money and people chose to not attend for a second time. However, the dramatic increase in the Burning Man ticket price might be not a good solution to the soaring crowds: our results show that if the price of the ticket increases by $\$ 1$, the probability of attending Burning Man 
for the successive time(s) decreases by $1 \%$ compared to the situation when the price of the ticket remains the same.

\section{Typical Burners and theme camps}

Most of the respondents encompassed in our surveys (88\%) have already attended Burning Man event at least ones. The average age of the participant from our sample was 32 years. There were $65 \%$ males and $35 \%$ females in the sample. About $63 \%$ of our respondents were single and $83 \%$ of them were childless. About half of them had post-secondary (Bachelor or Master) education or even postgraduate (Ph.D. or MBA) from prestigious universities in the United States or abroad (such as the University of California, Berkeley, Columbia University, Kings College London, or the University of Sydney, just to name a few). The profile of a typical "Burner" is shown in the infographics in Figure 3 that follows.

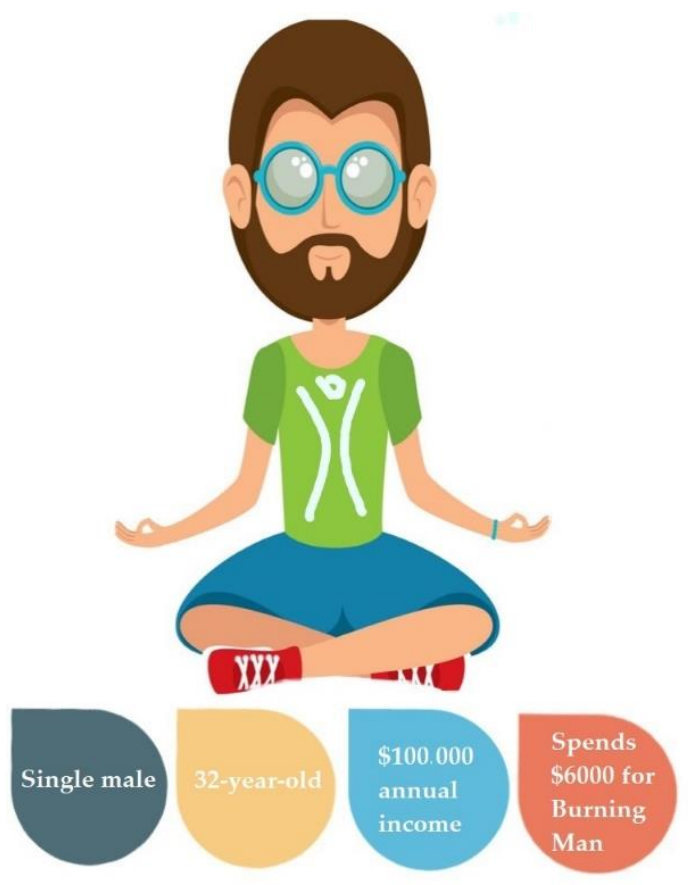

Figure 3. Profile of a typical Burning Man attendee (called "Burner"). Source: Own results

Moreover, all Burning Man participants are free to submit their proposals for the so-called "theme camps". Theme camps should be created in accordance with Burning Man principles and offer some form on interactivity. The more effort and money are put into the camp, the larger is the probability of the successful proposal (May, 2005). If the proposal is selected by the Burning Man Organization, the successful team receives tickets and can enter the Burning Man premises several days in advance as an "early arrival team" for setting up the camp. It appears that most of the experienced Burners typically join a camp or know how to do so. There is a reason for that: members of the theme camps at Burning Man have lower average costs per person (including both travel and ticket) than non-camp participants. Moreover, it turns out that Burning Man participants who are the members of a theme camp tend to choose more advanced options for spending their time and know better what to expect from the whole concept of the festival.

\section{Conclusions}

Quite contrary to what most of the people think, Burning Man is not a "hippie" or "bohemian" festival but a lucrative and expensive event in the desert as well as a modern playground for the representatives of today's elites. A local event has overgrown its creators and has become a global phenomenon and a trend-setter of festival art. However, it appears that some wealthier participants 
of Burning Man are often fed up with harsh conditions of surviving in the lifeless desert after their first visit and refuse to return to the festival in the consecutive years.

Overall, one can notice that Burning Man is not for everyone due to its extremities and peculiarities. Once a person decides to attend the event, she or he might discover that it might be quite burdensome and expensive to do so. Despite that, Burning Man attracts thousands of participants each year, much more than it can handle. Environmental protection regulations might limit further expansion of Burning Man festival in Nevada's Black Rock Desert, but the solution might be found in holding Burning Man regional events held in other places across United States and abroad. The global worldwide Burning Man community will have the capacity to accommodate everyone interested in the event and its underlying principles and will give them a chance to taste the unique spirit and magic of Burning Man.

\section{References}

- Brill, L. (2018). The first Year in the Desert. Available at: http://burningman.org/culture/history/brc-history/event-archives/1986-1991/firstyears/

- Burning Man Organization (2018). The 10 principles of Burning Man. Available at: http://burningman.org/culture/philosophical-center/10-principles/

- Chen, K. K. (2009a). Enabling creative chaos: The organization behind the Burning Man event. University of Chicago Press, Chicago, 240 pages

- Chen, K. K. (2009b). Authenticity at Burning Man. Contexts, 8(3), 65-67. https://doi.org/10.1525/ctx.2009.8.3.65

- Craig, C. S. (2013). Creating cultural products: Cities, context and technology. City, Culture and Society, 4(4), 195-202. https://doi.org/10.1016/j.ccs.2013.06.002

- Doherty, B. (2006). This Is Burning Man. Benbella Books, Dallas, 311 pages

- FIU (2018). Burning the Man, Academically. Florida International University library platform. Available at: https://library.fiu.edu/c.php?g=160170\&p=1048267

- Gilmore, L., \& Van Proyen, M. (Eds.). (2005). AfterBurn: Reflections on Burning Man. UNM Press

- Karlin, S. (2016). Burning Man's tech mastermind. IEEE Spectrum,53(1), 22-22. https://doi.org/10.1109/MSPEC.2016.7367452

- Kozinets, R. V. (2002). Can consumers escape the market? Emancipatory illuminations from Burning Man. Journal of Consumer Research, 29(1), 20-38. https://doi.org/10.1086/339919

- Kozinets, R. V. (2002). Desert pilgrim. Consumption, Markets and Culture, 5(2), 171-186. https://doi.org/10.1080/10263860290015602

- Kozinets, R. V., \& Sherry JR, J. F. (2004). Dancing on common ground: exploring the sacred at Burning Man. Rave culture and religion, 287-303.

- May, M. (2005). Theme Camps. Available at: http://www.sfgate.com/cgibin/article.cgi?f=/c/a/2005/08/31/BAGD0EFM9G1.DTL

- Radziwill, N. M., \& Benton, M. C. (2013). Burning man: Quality and innovation in the spirit of Deming. The Journal for Quality and Participation, 36(1), 7-11.

- Robinson, R. (2015). No Spectators! The art of participation, from Burning Man to boutique festivals in Britain. The Pop Festival: History, Music, Media, Culture, pp. 165-182.

- Sherry, J. F., Kozinets, R. V. (2007). Comedy of the commons: Nomadic spirituality and the Burning Man festival. Research in Consumer Behavior, 11, 119-147.

- Turner, F. (2009). Burning Man at Google: a cultural infrastructure for new media production. New Media \& Society, 11(1-2), 73-94. https://doi.org/10.1177/1461444808099575

- White, C. L. (2013). The Burning Man festival and the archaeology of ephemeral and temporary gatherings. Oxford Handbook of the Archaeology of the Contemporary World, Oxford University Press, Oxford, pp. 591-605. 